PENELITIAN

\title{
Perbandingan Efektifitas Antara Tramadol Dan Meperidin Untuk Pencegahan Menggigil Pasca Anestesi Umum
}

\section{Effectiveness Comparison Between Tramadol And Meperidine For Prevention of Post Anesthesia Shivering}

\author{
Himawan Sasongko ${ }^{\bowtie *}$ \\ * Bagian Anestesi dan Terapi Intensif Fakultas Kedokteran Universitas Diponegoro/ RSUP Dr. Kariadi Semarang. \\ $\square$ Korespondensi/correspondence :
}

\section{ABSTRACT}

Background : Post anesthesia shivering is common complication after anesthesia. It can causes uncomfortable situation and so many risk especially to the patient with no optimal condition, patient with severe chronic obstructive pulmonary disease or patient with heart failure. Post anesthesia shivering must be prevented or treated. The most commonly drug that used is meperidine.

Objective : The aim of this study is to proved that giving intra venous tramadol $2 \mathrm{mg}$ $\mathrm{kg}^{-1}$ as soon before the end of the surgery is more effective than intravenous meperidine $0.5 \mathrm{mg} \mathrm{kg}^{-1}$ as soon before the end of the surgery to prevent shivering after general anesthesia

Methods : This experimental study was designed as randomized post test only controlled group. Seventy two patients 16-60 year age, physical status ASA I-II, normal body weight underwent elective surgery with general anesthesia. Patient were fasted for 6 hours and receiving premedication midazolam $0.07 \mathrm{mg} \mathrm{kg}^{-1}$ and fentanyl $1.5 \mathrm{mg} \mathrm{kg}^{-1}$ intravenous 2 minutes before induction. Systolic blood pressure, diastolic blood pressure, mean arterial pressure, heart rate and $\mathrm{SaO}_{2}$ were measured 5 minutes before induction. Anesthesia was induced with thiopentone $5 \mathrm{mg} \mathrm{kg}^{-1}$. After loss of eyelashes reflex, patients were receiving atracurium besylate $0.5 \mathrm{mg} \mathrm{kg}^{-1}$ and intubation was done. Maintenance of anesthesia were using isoflurane $0.8-1.7$ vol\%, $\mathrm{N}_{2} \mathrm{O} 70 \%, \mathrm{O}_{2} 30 \%$ and incremental dose $0.2 \mathrm{mg} \mathrm{kg}^{-1}$ of atracurium besylate. Esophageal temperature was measured as soon as intubation done. Duration of operation was limited $2-3$ hours. At the end of surgery, inhalation drugs were stopped. After adequate spontaneous breathing and laryngeal reflex shown, randomization was done. Patients divided into three groups which were $T$ group (receiving tramadol $2 \mathrm{mg} \mathrm{kg}^{-1}$ ), M group (receiving meperidine $0.5 \mathrm{mg} \mathrm{kg}^{-1}$ ) and $\mathrm{K}$ group (receiving $\mathrm{NaCl}$ 0,9\%). Extubation was done 5 minutes after the drug was given. Systolic blood pressure, diastolic blood pressure, mean arterial pressure, heart rate and $\mathrm{SaO}_{2}$ were measured as soon as after extubation and every 5 minutes for 30 minutes long. Body temperature were measured as soon as and 15 minutes after extubation. After extubation patients were receiving oxygen $6 \mathrm{~L} /$ minute face mask. Statistical analysis were performed by One-way Anova and p-value $<0.05$ was considered significant.

Results : Basic data, clinical characteristic data before induction, comparison of measurement systolic blood pressure, diastolic blood pressure, mean arterial pressure, 
heart rate and $\mathrm{SaO}_{2}$ were not significantly different $(p>0,05)$ except heart rate 30 minutes after extubation between tramadol group and control group $(p<0,05)$. Incidence and degree of shivering between tramadol group and meperidine group were not significantly different. Differences of body temperature 15 minutes after extubation and side effects of drug that showed between tramadol group and meperidine group were significantly different $(p<0,05)$.

Conclusions : Tramadol and meperidine have similar effectivity on the prevention of shivering after general anesthesia, but tramadol have lower side effect compare to meperidine.

Keywords : post anesthesia shivering, tramadol, meperidine.

\section{ABSTRAK}

Latar belakang : Menggigil pasca anestesi merupakan komplikasi yang cukup sering terjadi. Menggigil menimbulkan keadaan yang tidak nyaman dan berbagai resiko terutama bagi pasien dengan kondisi fisik yang tidak optimal, pasien dengan penyakit paru obstruktif menahun yang berat, atau pasien dengan gangguan kerja pada jantung. Karena itu menggigil harus segera dicegah atau diatasi. Sampai saat ini obat yang paling sering digunakan adalah meperidin.

Tujuan : Membuktikan bahwa pemberian tramadol $2 \mathrm{mg} / \mathrm{kgBB}$ intra vena menjelang akhir operasi lebih efektif daripada meperidin $0,5 \mathrm{mg} / \mathrm{kgBB}$ intra vena menjelang akhir operasi untuk mencegah kejadian menggigil pasca anestesi umum.

Metode : Merupakan penelitian eksperimental dengan desain "randomized post test only controlled group" pada 72 pasien usia 16 - 60 tahun, status fisik ASA I - II, berat badan normal yang menjalani operasi dengan anestesia umum. Pasien dipuasakan 6 jam dan diberikan premedikasi midazolam $0,07 \mathrm{mg} / \mathrm{kgBB}$ dan fentanil $1,5 \mu \mathrm{g} / \mathrm{kgBB}$ intra vena 2 menit sebelum induksi. Tekanan darah diastolik, tekanan darah sistolik, tekanan arteri rerata, laju jantung dan $\mathrm{SaO}_{2}$ diukur 5 menit sebelum induksi. Induksi anestesi dilakukan dengan thiopental $5 \mathrm{mg} / \mathrm{kgBB}$. Setelah reflek bulu mata hilang, diberikan atrakurium besilat $0,5 \mathrm{mg} / \mathrm{kgBB}$ dan dilakukan intubasi endotrakea. Rumatan anestesi menggunakan isofluran $0,8-1,7 \mathrm{vol} \%, \mathrm{~N}_{2} \mathrm{O} 70 \%$ dan $\mathrm{O}_{2} 30 \%$. Atrakurium intermiten diberikan dengan dosis $0,2 \mathrm{mg} / \mathrm{kgBB}$. Temperatur esofagus diukur segera setelah induksi. Lama operasi dibatasi antara $2-3$ jam. Pada akhir operasi, obat inhalasi dihentikan. Setelah nafas spontan adekuat, reflek laringeal positip dilakukan randomisasi. Pasien dibagi menjadi tiga kelompok yaitu kelompok $\mathrm{T}$ (mendapat tramadol $2 \mathrm{mg} / \mathrm{kgBB}$ ), kelompok $\mathrm{M}$ (mendapat meperidin 0,5 mg/kgBB) dan kelompok $\mathrm{K}$ (mendapat $\mathrm{NaCl} \mathrm{0,9 \% ).} \mathrm{Ekstubasi}$ dilakukan 5 menit setelah perlakuan. Tekanan darah diastolik, sistolik, tekanan arteri rerata, laju jantung dan $\mathrm{SaO}_{2}$ diukur dan dicatat segera setelah ekstubasi dan tiap lima menit selama 30 menit. Suhu tubuh diukur segera dan 15 menit setelah ekstubasi. Pasca ekstubasi pasien diberi oksigen $6 \mathrm{~L} /$ menit. Uji statistik menggunakan One-way ANOVA, dengan derajat kemaknaan $p<0,05$.

Hasil : Data dasar, data karakteristik klinis sebelum induksi, perbandingan pengukuran tekanan darah diastolik, tekanan darah sistolik, tekanan arteri rerata, laju jantung dan $\mathrm{SaO}_{2}$ berbeda tidak bermakna $(p>0,05)$ kecuali laju jantung 30 menit pasca ekstubasi antara kelompok tramadol dan kontrol berbeda bermakna $(p<0,05)$. Kejadian dan derajat menggigil kelompok tramadol dan meperidin berbeda tidak bermakna $(p>0,05)$. Perbedaan suhu tubuh kelompok tramadol dan meperidin 15 menit pasca ekstubasi dan efek samping obat yang timbul berbeda bermakna $(p<0,05)$. 
Kesimpulan : Tramadol dan meperidin mempunyai efektifitas yang sama dalam mencegah menggigil pasca anestesi umum, tetapi tramadol mempunyai efek samping obat yang lebih rendah dibandingkan meperidin.

Kata kunci : menggigil pasca anestesi, tramadol, meperidin.

\section{PENDAHULUAN}

Penyulit yang terjadi pasca anestesi dapat ditimbulkan oleh berbagai faktor yaitu tindakan pembedahan, tindakan anestesi atau faktor penderita itu sendiri. ${ }^{1}$ Salah satu diantara penyulit yang cukup sering dijumpai selama pemulihan adalah menggigil. ${ }^{1-6}$ Angka kejadian menggigil selama pemulihan anestesi ini antara $5 \%$ hingga $65 \%$. ${ }^{4,5}$

Menggigil menimbulkan keadaan yang tidak nyaman bagi pasien, selain itu menggigil juga menimbulkan resiko. ${ }^{2}$ Resiko utama yang terjadi pada pasien menggigil pasca anestesi adalah peningkatan proses metabolisme (dapat mencapai $400 \%$ ) dan memperberat nyeri pasca operasi. $^{7,8}$ Aktivitas otot yang meningkat akan meningkatkan konsumsi oksigen dan peningkatan produksi karbondioksida. ${ }^{1}$ Hal ini dapat berbahaya bagi pasien dengan kondisi fisik tidak optimal, penyakit paru obstruktif menahun yang berat atau gangguan kerja pada jantung. ${ }^{1,4}$ Asidosis laktat dan asidosis respiratorik dapat terjadi bila ventilasi dan kerja dari jantung tidak meningkat secara proporsional $^{4,9}$, karena itu menggigil harus segera dicegah atau diatasi.
Cara yang dapat dilakukan untuk mencegah atau mengatasi menggigil pasca anestesi adalah menjaga suhu tubuh tetap normal selama tindakan pembedahan ${ }^{9}$, atau dengan memberikan obat-obatan. ${ }^{8,10}$

Penghangatan secara aktif terhadap pasien merupakan suatu cara yang dapat digunakan, meskipun hasilnya tidak selalu efektif karena menggigil pasca anestesi tidak selalu terjadi pada pusat pengaturan suhu, oleh karena core temperature tidak selalu rendah pada pasien yang mulai mengalami menggigil selama masa pemulihan dari tindakan anestesi. ${ }^{4}$

Meperidin adalah obat yang dianjurkan untuk mengatasi kejadian menggigil pasca anestesi. Efek anti menggigil dari meperidine adalah pada reseptor-k dari reseptor opioid. Meperidin dosis kecil (10 - $25 \mathrm{mg})$ sering digunakan sebagai terapi menggigil pasca anestesi. Dosis yang dibutuhkan untuk pencegahan terhadap menggigil adalah $0,5 \mathrm{mg} / \mathrm{kgBB}$, yang dapat menurunkan angka kejadian menggigil $32 \%-80 \%{ }^{6,7}$ Meperidin mempunyai efek samping yang spesifik yaitu sedasi, euforia, pruritus dan akan memperberat rasa mual dan muntah 
pasca operasi. Selain itu juga kejadian depresi pernafasan cukup tinggi. ${ }^{4}$

Klonidin dapat dipakai untuk mencegah kejadian menggigil pasca anestesi. Mekanisme yang terjadi diduga pada penurunan aktifitas simpatik, efek analgetik, penghambatan reflek spinal dan efek sedasi. Tetapi penggunaan klonidin dibatasi oleh efek hipotensi dan bradikardi. ${ }^{10}$ Hasil dari beberapa penelitian yang menggunakan klonidin menunjukkan hasil yang tidak selalu memuaskan. Karena itu efek klonidin terhadap menggigil pasca anestesi diduga berhubungan dengan waktu, dosis dan cara pemberian obat. ${ }^{10}$ Klonidin efektif bila diberikan dengan dosis $3 \mathrm{mg} / \mathrm{kgBB}$ intravena menjelang akhir operasi. ${ }^{6,10}$

\section{Tramadol}

hidroklorid

(tramadol) adalah suatu obat analgesik opioid yang bekerja secara sentral. Tramadol menghambat pengambilan kembali (re-uptake) norepinefrin dan 5hidroksitriptamin diujung serabut saraf, memfasilitasi pelepasan 5hidroksitriptamin, mengaktivasi reseptor opioid-m, dan sedikit mempengaruhi reseptor $\mathrm{d}$ atau $\mathrm{k}^{11,12}$ Semua mekanisme ini akan mempengaruhi pusat pengaturan suhu. ${ }^{2}$ Karena itu obat ini dapat dipakai untuk mencegah menggigil pasca anestesi. Keuntungan yang didapat dengan memakai tramadol selain pengaruh terhadap hemodinamik yang tidak bermakna $^{13}$, obat ini menyebabkan depresi pernafasan dan sedasi yang lebih sedikit dibanding dengan meperidin. ${ }^{12-14}$ Sehingga dapat dikatakan penggunaannya lebih aman, terutama pada pasien dengan kondisi kardiorespirasi yang tidak baik. Disamping itu angka kejadian mual dan muntah relatif lebih kecil dibanding meperidin. ${ }^{11} \quad$ Bhatnagar dkk. menggunakan dosis $1 \mathrm{mg} / \mathrm{kgBB}$ intra vena untuk mengobati kejadian menggigil pasca anestesi dan mendapatkan hasil $80 \%$ pasien berhenti menggigil dalam rentang waktu 10 menit setelah obat diberikan. ${ }^{14}$

S. Mathews dkk. yang melakukan penelitian menggunakan tramadol dosis $1 \mathrm{mg} / \mathrm{kgBB}$ dan $2 \mathrm{mg} /$ $\mathrm{kgBB}$ yang diberikan pada saat mulai penutupan luka operasi pada pasien yang dilakukan anestesia umum menyimpulkan bahwa tramadol efektif dan aman untuk mencegah terjadinya menggigil pasca anestesi. ${ }^{15}$ Hal yang sama juga ditunjukkan oleh hasil penelitian De Witte dkk., tapi dengan dosis $3 \mathrm{mg} / \mathrm{kgBB} .{ }^{16}$ Tsai YC dkk. melakukan penelitian dengan menggunakan tramadol dosis $0,5 \mathrm{mg} /$ $\mathrm{kgBB}$ intravena untuk mencegah menggigil pasca anestesi epidural. Hasil yang didapatkan ternyata tramadol mempunyai efektifitas yang sama dengan meperidin dosis $0,5 \mathrm{mg} /$ $\mathrm{kgBB}$ intravena dalam mencegah menggigil pasca anestesi epidural. ${ }^{2}$ Sedangkan Chan AMH dkk. menyimpulkan tramadol dosis $0,25 \mathrm{mg}$ / $\mathrm{kgBB}$ intravena efektif mengatasi 
menggigil pada pasien seksio cesarea yang dilakukan regional anestesi dengan efek samping yang minimal. ${ }^{12}$

Pada penelitian ini efektifitas pencegahan menggigil antara tramadol dan meperidin dilakukan pada sampel penelitian yang semuanya dilakukan anestesia umum, dimana hal ini merupakan orisinalitas dari penelitian ini.

\section{METODE}

Penelitian ini merupakan penelitian eksperimental dengan desain penelitian "randomized post test only controlled group design". Kelompok penelitian dibagi menjadi tiga kelompok. Kelompok $\mathrm{T}$ mendapat tramadol $2 \mathrm{mg} / \mathrm{kgBB}$ IV menjelang akhir operasi, Kelompok M mendapat meperidin $0,5 \mathrm{mg} / \mathrm{kgBB}$ IV menjelang akhir operasi. Kelompok K mendapat larutan $\mathrm{NaCl} \quad 0,9 \%$ IV menjelang akhir operasi.

Kriteria inklusi diantaranya usia antara 16 - 60 tahun, status fisik ASA I - II, menjalani operasi dengan anestesia umum, lama operasi $2-3$ jam, tidak ada kontra indikasi pemakaian obat anestesi yang digunakan yaitu isofluran, tramadol dan meperidin, berat badan normal (Brocca $90 \%-110 \%)$.

Kriteria eksklusi diantaranya
pasien yang memerlukan obat
vasokonstrik-tor selama pembedahan,
lama operasi $<2$ jam atau $>3$ jam.
Mengingat keterbatasan waktu dan jumlah populasi, maka dalam penelitian ini pemilihan sampel dilakukan dengan consecutive random sampling, dimana setiap penderita yang memenuhi kriteria yang telah disebutkan diatas dimasukkan dalam sampel penelitian sampai jumlah yang diperlukan terpenuhi.

Data yang terkumpul dibagi menjadi tiga kelompok, yaitu satu kelompok kontrol (Kelompok K) dan dua kelompok perlakuan, yaitu Kelompok T (Tramadol) dan Kelompok M (Meperidin). Data-data tersebut meliputi data demografi dasar, status fisik, tekanan darah, laju jantung, tekanan arteri rerata, saturasi oksigen, suhu tubuh, skor menggigil, dan durasi menggigil dan efek samping obat yang timbul.

Data diolah dengan komputer menggunakan program SPSS (Statistical Package for Social Sciences) Windows version 11.00 dan dinyatakan dalam rerata \pm simpang baku ( mean $\pm S D$ ). Uji statistik dilakukan dengan menggunakan Oneway ANOVA, dengan derajat kemaknaan yaitu $p<0,05$. Penyajian dalam bentuk tabel dan grafik.

\section{HASIL}

Dari Tabel 1 mengenai karakteristik penderita ketiga kelompok perlakuan diatas dapat kita lihat bahwa dari uji statistik menggunakan one-way Anova menunjukkan perbedaan yang 
tidak bermakna $(p>0,05)$ dari semua variabel yaitu umur, jenis kelamin, berat badan, tinggi badan, jenis operasi, lama operasi dan status fisik penderita.

Data karakteristik klinis (tekanan darah diastolik, tekanan darah sistolik, tekanan arteri rerata, laju jantung dan saturasi oksigen) penderita lima menit sebelum dilakukan induksi anestesi dapat dilihat pada Tabel 2.

Dari data karakteristik klinis penderita diatas, dengan mengguna-kan uji One-way Anova maka didapat-kan perbedaan yang tidak bermakna $(\mathrm{p}>$ $0,05)$ pada seluruh variabel pada ketiga kelompok perlakuan.

Atas dasar hasil uji statistik yang dilakukan pada data dasar subyek penelitian dan karakteristik klinis penderita lima menit sebelum induksi pada ketiga kelompok perlakuan yang menunjukkan perbedaan yang tidak bermakna, maka antara ketiga kelompok dapat dikatakan homogen dan semuanya layak untuk diperbandingkan.

Dari Tabel 3 diatas dapat dilihat bahwa pada kelompok tramadol terjadi peningkatan tekanan darah diastolik pada sepuluh menit setelah pemberian tramadol, peningkatan tekanan darah sistolik lima menit setelah pemberian tramadol dan peningkatan laju jantung pada limabelas menit setelah pemberian tramadol. Peningkatan laju jantung juga didapatkan pada kelompok meperidin dimana laju jantung meningkat pada limabelas menit setelah ekstubasi dilakukan.

Dari uji statistik yang dilakukan dengan menggunakan uji One-way Anova, semua variabel pengukuran (TDS, TDD, TAR, LJ dan $\mathrm{SaO}_{2}$ ) pada 5 menit sebelum induksi, segera setelah ekstubasi, 5 menit, 10 menit, 15 menit, 20 menit, 25 menit dan 30 menit pasca ekstubasi dari ketiga kelompok perlakuan semuanya menunjukkan perbedaan yang tidak bermakna $(p>0,05)$, kecuali perbandingan laju jantung antara kelompok tramadol dan kontrol pada 30 menit pasca ekstubasi menunjukkan perbedaan bermakna $(\mathrm{p}<$ $0,05)$.

Dari Tabel 4 dapat dilihat bahwa kejadian menggigil dan derajat menggigil pada kelompok tramadol dan kelompok meperidin menunjukkan perbedaan yang tidak bermakna $(p>$ 0,05). Sedangkan apabila kelompok tramadol dan kelompok meperidin dibandingkan dengan kelompok kontrol, keduanya menunjukkan perbedaan yang bermakna $(\mathrm{p}<0,05)$. Durasi menggigil dari ketiga kelompok perlakukan menunjukkan perbedaan yang tidak bermakna $(p>0,05)$.

Dari Tabel 5 diatas dapat kita lihat perbedaan suhu tubuh yang bermakna hanya terlihat pada kelompok tramadol dibandingkan dengan kelompok meperidin pada 15 menit pasca ekstubasi. Perbandingan pengukuran suhu pada ketiga kelompok perlakuan pada waktu yang lain 
menunjukkan perbedaan yang tidak bermakna $(p>0,05)$.

Dari Tabel 6 diatas, dari uji statistik yang dilakukan terlihat bahwa terdapat perbedaan yang bermakna pada efek samping obat yang timbul pada kelompok tramadol dibandingkan meperidin $(\mathrm{p}<0,05)$. Sedangkan pada kelompok tramadol dan kelompok kontrol menunjukkan perbedaan yang tidak bermakna $(\mathrm{p}>0,05)$.

\section{PEMBAHASAN}

Penelitian yang dilakukan ini adalah membandingkan efektifitas antara tramadol dan meperidin dalam mencegah terjadinya menggigil pasca anestesi. Penderita dibagi menjadi tiga kelompok (Kelompok T, M dan K) yang masing-masing terdiri dari 24 orang penderita.

Dari data karakteristik penderita yang meliputi umur, jenis kelamin, berat badan, tinggi badan, jenis operasi, lama operasi dan status fisik penderita serta karakteristik klinis penderita lima menit sebelum induksi, dapat kita lihat tidak didapatkan perbedaan yang bermakna dari ketiga kelompok perlakuan. Variabel-variabel tersebut diatas telah dikendalikan dengan teknik inklusi dan eksklusi. Dengan demikian ketiga kelompok dapat dikatakan homogen dan layak untuk diperbandingkan.

Hasil pengukuran tanda vital yang meliputi tekanan darah sistolik, tekanan darah diastolik, tekanan arteri rerata, laju jantung dan saturasi $\mathrm{O}_{2}$ pada 5 menit sebelum induksi, segera setelah ekstubasi, 5 menit, 10 menit, 15 menit, 20 menit, 25 menit dan 30 menit pasca ekstubasi dari ketiga kelompok perlakuan semuanya menunjukkan perbedaan yang tidak bermakna, kecuali perbandingan laju jantung antara kelompok tramadol dan kontrol pada 30 menit pasca ekstubasi menunjukkan perbedaan bermakna.

Pada kelompok tramadol terjadi peningkatan tekanan darah diastolik pada sepuluh menit setelah pemberian tramadol, peningkatan tekanan darah sistolik lima menit setelah pemberian tramadol dan peningkatan laju jantung pada limabelas menit setelah pemberian tramadol (Grafik 1). Meskipun secara substansial sistem kardiovaskuler tidak dipengaruhi secara bermakna, namun terdapat kenaikan tekanan darah setelah pemberian secara intravena. Selama tindakan anestesi, pemberian tramadol akan menyebabkan tekanan darah sistolik meningkat $14-16 \mathrm{mmHg}$ dan diastolik meningkat $10-12 \mathrm{mmHg}$ dalam $4-6$ menit pertama setelah pemberian. ${ }^{17}$ Tahanan vaskuler perifer meningkat hingga $23 \%$ pada $2-10$ menit pertama setelah pemberian, dan kerja jantung meningkat hingga 15 $20 \%$ pada periode yang sama. ${ }^{13,17}$ Peningkatan laju jantung juga didapatkan pada kelompok meperidin dimana laju jantung meningkat pada 
limabelas menit setelah ekstubasi dilakukan.

Pada kelompok tramadol, kenaikan tekanan darah baik diastolik maupun sistolik serta peningkatan laju jantung tidak melebihi $25 \%$ dari data dasar sebelum dilakukan tindakan anestesi. Kenaikan tekanan darah ini secara klinis masih tidak berbahaya oleh karena masih dalam rentang normal autoregulasi dan kenaikan tidak melebihi $25 \%$ dari data dasar. Hipertensi intraoperatif didefinisikan sebagai peningkatan tekanan darah sebesar 25\% dari nilai sebelum dilakukan operasi. Hipertensi akan meningkatkan kerja jantung dengan meningkatnya afterload dan tegangan dinding ventrikel kiri. Hal ini biasanya berhubungan dengan takikardi dan akan sangat berbahaya pada pasien dengan penyakit jantung iskemik atau pembesaran ventrikel kiri. Selain itu, hipertensi juga akan meningkatkan resiko terjadinya iskemia, infark dan/ atau perdarahan pada organ lain seperti otak. ${ }^{18}$

Kejadian menggigil dan derajat menggigil pada kelompok tramadol dan kelompok meperidin menunjukkan perbedaan yang tidak bermakna. Dari 24 pasien, terdapat 4 pasien $(16,6 \%)$ dari masing-masing kelompok yang mengalami kejadian menggigil setelah dilakukan tindakan anestesi. Derajat menggigil yang terjadi semuanya ada pada derajat I, yaitu tremor intermiten dan ringan pada rahang dan otot-otot leher. Sedangkan apabila kelompok tramadol dan kelompok meperidin dibandingkan dengan kelompok kontrol, keduanya menunjukkan perbedaan yang dapat dikatakan sangat bermakna $(p=0,000)$. Dari 24 pasien pada kelompok kontrol, 13 pasien (54,16\%) mengalami kejadian menggigil pasca anestesi. Dari 13 kejadian tersebut, 7 pasien mengalami menggigil derajat I, 3 pasien derajat II, 2 pasien derajat III dan 1 pasien derajat IV (Grafik 2). Durasi menggigil dari ketiga kelompok perlakukan menunjukkan perbedaan yang tidak bermakna.

S. Mathews dkk. yang melakukan penelitian menggunakan tramadol dosis $1 \mathrm{mg} / \mathrm{kgBB}$ dan $2 \mathrm{mg} /$ $\mathrm{kgBB}$ yang diberikan pada saat mulai penutupan luka operasi pada pasien yang dilakukan anestesia umum menyimpulkan bahwa tramadol efektif dan aman untuk mencegah terjadinya menggigil pasca anestesi. ${ }^{15}$ Hal yang sama juga ditunjukkan oleh hasil penelitian De Witte dkk, tapi dengan dosis $3 \mathrm{mg} / \mathrm{kgBB} .^{16,19}$ Pada penelitian De Witte dkk., menggigil pasca anestesi tidak terjadi pada kelompok yang menerima tramadol $3 \mathrm{mg} / \mathrm{kgBB}$ intra vena yang diberikan saat mulai penutupan luka, tetapi pada kelompok kontrol menggigil terjadi pada $60 \%$ pasien. Kesimpulan dari penelitian De Witte dkk. adalah pemberian tramadol dosis tinggi pada akhir operasi dapat mencegah terjadinya menggigil pasca 
anestesi tanpa pemanjangan waktu ekstubasi dan waktu di ruang pulih sadar menjadi lebih singkat. ${ }^{19}$ Kedua penelitian ini hanya membandingkan dosis tramadol yang digunakan untuk mencegah menggigil pasca anestesi, tetapi tidak membandingkan dengan obat lainnya.

Tsai YC dkk. melakukan penelitian dengan menggunakan tramadol dosis $0,5 \mathrm{mg} / \mathrm{kgBB}$ intravena untuk mencegah menggigil pasca anestesi epidural. Hasil yang didapatkan ternyata tramadol mempunyai efektifitas yang sama dengan meperidin dosis $0,5 \mathrm{mg} / \mathrm{kgBB}$ intravena dalam mencegah menggigil pasca anestesi epidural. ${ }^{2}$ Sedangkan Chan AMH dkk. menyimpulkan tramadol dosis $0,25 \mathrm{mg} / \mathrm{kgBB}$ intravena efektif mengatasi menggigil pada pasien seksio cesarea yang dilakukan regional anestesi dengan efek samping yang minimal. ${ }^{12}$

\section{Tramadol}

hidroklorid (tramadol) adalah suatu obat analgesik opioid yang bekerja secara sentral. Tramadol menghambat pengambilan kembali (re-uptake) norepinefrin dan 5hidroksitriptamin diujung serabut saraf, memfasilitasi pelepasan 5hidroksitriptamin dan mengaktivasi reseptor opioid-m, dan sedikit mempengaruhi reseptor $\mathrm{d}$ atau $\mathrm{k}^{11,12}$ Semua mekanisme ini akan mempengaruhi pusat pengaturan suhu. $^{2,19}$ Karena itu tramadol dapat dipakai untuk mencegah menggigil pasca anestesi. Keuntungan yang didapat dengan memakai tramadol selain pengaruh terhadap hemodinamik yang tidak bermakna ${ }^{13}$ adalah obat ini menyebabkan depresi pernafasan dan sedasi yang lebih sedikit dibanding dengan meperidin. ${ }^{12-14}$ Sehingga dapat dikatakan penggunaan tramadol lebih aman, terutama pada pasien dengan kondisi kardiorespirasi yang tidak baik. Disamping itu angka kejadian mual dan muntah relatif lebih kecil dibanding meperidin. ${ }^{11}$ Dari berbagai hal yang telah disebutkan diatas dapat diambil kesimpulan bahwa tramadol dosis $1 \mathrm{mg} /$ $\mathrm{kgBB}$ hingga $3 \mathrm{mg} / \mathrm{kgBB}$ efektif dalam mencegah terjadinya menggigil pasca anestesi, khususnya anestesi umum.

$$
\text { Selain untuk mencegah }
$$
menggigil pasca anestesi, tramadol juga dapat digunakan untuk terapi menggigil pasca anestesi. Pausawasdi S dkk. melakukan penelitian menggunakan tramadol hidroklorid dosis $1 \mathrm{mg} / \mathrm{kgBB}$ secara intravena yang diberikan kepada 110 pasien dewasa yang mengalami menggigil pasca anestesi. Semua pasien dapat sembuh dari menggigil dalam waktu 45 detik sampai 6 menit, dimana $47 \%$ sembuh dari menggigil kurang dari 2 menit setelah penyuntikan tramadol. Hanya 5 pasien yang mengalami menggigil kembali setelah 10 sampai 30 menit dan hal ini dapat dengan mudah diatasi dengan pemberian ulang tramadol. Efek samping yang timbul sangat kecil dan tidak dibutuhkan penanganan dengan obat-obatan. ${ }^{20}$ 
Dari hasil pengukuran suhu tubuh yang dilakukan selama tindakan anestesi, perbedaan suhu tubuh yang bermakna hanya terlihat pada kelompok tramadol dibandingkan dengan kelompok meperidin pada 15 menit pasca ekstubasi. Perbandingan pengukuran suhu pada ketiga kelompok perlakuan pada waktu yang lain, khususnya setelah tindakan anestesi umum, menunjukkan perbedaan yang tidak bermakna. Hal ini menunjukkan bahwa pemberian obat-obatan seperti tramadol atau meperidin cukup efektif dalam mengurangi kejadian menggigil pasca anestesi, selain untuk mengurangi terjadinya nyeri pasca pembedahan.

Pada temperatur inti tubuh yang kritis, pada tingkat hampir tepat $37,1^{\circ} \mathrm{C}$ terjadi perubahan drastis pada kecepatan kehilangan panas dan kecepatan pembentukan panas. Pada temperatur diatas tingkat ini, kecepatan kehilangan panas lebih besar dari kecepatan pembentukan panas, sehingga suhu tubuh turun dan mencapai kembali tingkat $37,1^{\circ} \mathrm{C}$. Pada temperatur dibawah tingkat ini, kecepatan pembentukan panas lebih besar dari kecepatan kehilangan panas sehingga temperatur tubuh meningkat dan kembali mencapai tingkat $37,1^{\circ} \mathrm{C}$. Tingkat temperatur kritis ini disebut dengan "set-point" dari mekanisme pengaturan temperatur. Semua mekanisme pengaturan temperatur tubuh harus terus menerus berupaya mengembalikan temperatur tubuh kembali ke tingkat set-point ini. ${ }^{8}$

Pada penelitian ini menunjukkan efek samping obat yang timbul akibat pemberian meperidin lebih tinggi dibandingkan pemberian tramadol. Pada kelompok meperidin, terdapat 6 pasien (25\%) mengalami kejadian mual dan 2 orang pasien $(8,3 \%)$ mengalami kejadian mual muntah. Pada kelompok tramadol, hanya 2 pasien $(8,3 \%)$ yang mengalami kejadian mual dan berbeda bermakna jika dibandingkan kelompok meperidin. Bila kelompok tramadol dibandingkan dengan kelompok kontrol menunjukkan perbedaan yang tidak bermakna (Grafik 3).

Dibandingkan dengan morfin dan obat golongan opioid yang lainnya, angka kejadian mual dan muntah akibat pemberian meperidin lebih tinggi, tetapi durasinya lebih pendek. Kejadian ini oleh karena adanya stimulasi pada daerah medullary chemoreceptor trigger zone. $^{21}$

Sarim BY dan Budiono U. (2011) melakukan penelitian Ketamin dan Meperidin Untuk Pencegahan Menggigil Pasca Anestesi Umum. Hasil yang didapatkan ketamin $0,25 \mathrm{mg} / \mathrm{kgBB}$ dan meperidin $0,5 \mathrm{mg} / \mathrm{kgBB}$ mempunyai efektifitas yang sama dalam mencegah menggigil pasca anestesi umum, tetapi meperidin mempunyai efek samping mual yang lebih tinggi dibandingkan ketamin. $^{22}$ Sementara dari penelitian Fatoni dkk. didapatkan bahwa meperidin $0,4 \mathrm{mg} / \mathrm{kgBB}$ dan ondansetron $0,1 \mathrm{mg} /$ kgBB mempunyai kejadian mual pada 
meperidin $(12,5 \%) \quad$ lebih tinggi dibanding ondansetron $(0 \%){ }^{23}$

Penelitian yang dilakukan oleh Budiono pada pasien sectio cesaerea dengan anestesi spinal, memberikan hasil bahwa meperidin $25 \mathrm{mg}$, ketamin 25 mg dan klonidin 75 mcg mempunyai efektifitas yang sama untuk terapi menggigil pada sectio cesarea dengan anestesi spinal. Efek samping mual muntah terjadi pada semua kelompok. ${ }^{24}$ Pada sistem gastrointestinal, tramadol dapat menyebabkan mual, muntah dan konstipasi, namun lebih rendah jika dibandingkan dengan opioid yang lain, jarang menyebabkan kerusakan mukosa gastrointestinal. ${ }^{13}$ Hal ini merupakan salah satu keuntungan penggunaan tramadol jika dibandingkan meperidin untuk pencegahan menggigil pasca anestesi.

Efek samping obat yang berhubungan dengan respirasi seperti penurunan tidal volume dan depresi pernafasan yang biasanya muncul akibat pemberian golongan opioid, pada penelitian ini tidak terjadi oleh karena pemberian obat dilakukan secara perlahan-lahan dan konsentrasi obat yang digunakan diperkecil.

\section{SIMPULAN}

Tramadol dan meperidin mempunyai efektifitas yang sama dalam mencegah terjadinya menggigil pasca anestesi. Tramadol mempunyai efek samping obat yaitu mual dan muntah yang lebih rendah jika dibandingkan meperidin. Tramadol mempunyai pengaruh terhadap hemodinamik dan kardiovaskuler yang tidak bermakna bila diberikan secara intravena dengan dosis $2 \mathrm{mg} / \mathrm{kgBB}$. 
Tabel 1. Data dasar subyek penelitian ketiga kelompok perlakuan.

\begin{tabular}{|c|c|c|c|c|}
\hline Variabel & $\begin{array}{c}\text { Kelompok T } \\
(\mathrm{n}=24)\end{array}$ & $\begin{array}{c}\text { Kelompok M } \\
\quad(\mathrm{n}=24)\end{array}$ & $\begin{array}{c}\text { Kelompok K } \\
(\mathrm{n}=24)\end{array}$ & $\mathbf{p}$ \\
\hline Umur (tahun) & $41,79 \pm 8,00$ & $37,54 \pm 12,59$ & $38,83 \pm 11,69$ & 0,391 \\
\hline \multicolumn{5}{|l|}{ Jenis kelamin } \\
\hline Perempuan & 16 & 14 & 15 & 0,843 \\
\hline Laki-laki & 8 & 10 & 9 & \\
\hline Berat badan (kg) & $56,54 \pm 6,41$ & $56,75 \pm 6,78$ & $57,58 \pm 9,70$ & 0,887 \\
\hline Tinggi badan $(\mathrm{cm})$ & $161,21 \pm 6,75$ & $159,67 \pm 5,94$ & $160,50 \pm 7,30$ & 0,728 \\
\hline \multicolumn{5}{|l|}{ Jenis operasi } \\
\hline Ginekologi & 7 & 6 & 9 & \\
\hline Orthopaedi & 3 & 2 & 2 & \\
\hline Digestif & 7 & 7 & 6 & 0,694 \\
\hline Onkologi & 5 & 7 & 5 & \\
\hline THT & 2 & 2 & 2 & \\
\hline Lama operasi (menit) & $148,48 \pm 21,20$ & $148,13 \pm 23,95$ & $147,75 \pm 20,70$ & 0,991 \\
\hline \multicolumn{5}{|l|}{ Status fisik } \\
\hline ASA I & 14 & 19 & 19 & 0,183 \\
\hline ASA II & 10 & 5 & 5 & \\
\hline
\end{tabular}

Keterangan : Uji statistik menggunakan One-way Anova, dengan derajat kemaknaan $\mathrm{p}<0,05$.

Tabel 2. Data karakteristik klinis penderita lima menit sebelum induksi.

\begin{tabular}{lcccc}
\hline \multicolumn{1}{c}{ Variabel } & $\begin{array}{c}\text { Kelompok T } \\
(\mathrm{n}=24)\end{array}$ & $\begin{array}{c}\text { Kelompok M } \\
(\mathrm{n}=24)\end{array}$ & $\begin{array}{c}\text { Kelompok K } \\
(\mathrm{n}=24)\end{array}$ & p \\
\hline TD Diastolik & $76,42 \pm 9,27$ & $73,67 \pm 8,24$ & $77,88 \pm 9,31$ & 0,262 \\
\hline TD Sistolik & $125,00 \pm 13,65$ & $122,58 \pm 12,76$ & $126,21 \pm 13,14$ & 0,627 \\
\hline T A R & $92,17 \pm 9,72$ & $89,63 \pm 8,74$ & $93,42 \pm 9,59$ & 0,365 \\
\hline Laju jantung & $85,25 \pm 11,88$ & $84,71 \pm 15,09$ & $82,63 \pm 7,70$ & 0,725 \\
\hline Saturasi $\mathrm{O}_{2}$ & $98,92 \pm 0,72$ & $99,04 \pm 0,69$ & $98,96 \pm 0,86$ & 0,845 \\
\hline
\end{tabular}

Keterangan : TAR $=$ tekanan arteri rerata.

Semua data dinyatakan dalam rerata \pm simpang baku ( mean $\pm S D$ ).

Uji One-way Anova = berbeda tidak bermakna $(\mathrm{p}>0,05)$. 
Tabel 3. Perbandingan TDS, TDD, TAR, LJ dan $\mathrm{SaO}_{2}$ ketiga kelompok perlakuan.

\begin{tabular}{|c|c|c|c|c|c|c|}
\hline $\begin{array}{r}\text { Variabel } \\
\text { Waktu } \\
\end{array}$ & Kelompok T & Kelompok M & Kelompok K & $\mathbf{p}^{*}$ & $\mathbf{p} * *$ & $\mathbf{p}^{* * *}$ \\
\hline \multicolumn{7}{|l|}{ TD Diastolik } \\
\hline 5' pra induksi & $76,42 \pm 9,27$ & $73,67 \pm 8,24$ & $77,88 \pm 9,31$ & 0,291 & 0,575 & 0,108 \\
\hline 0' pasca ekstubasi & $73,33 \pm 6,12$ & $72,71 \pm 5,65$ & $74,21 \pm 5,87$ & 0,714 & 0,608 & 0,380 \\
\hline 5' pasca ekstubasi & $73,71 \pm 5,85$ & $72,88 \pm 5,46$ & $74,71 \pm 5,86$ & 0,616 & 0,547 & 0,271 \\
\hline 10' pasca ekstubasi & $76,08 \pm 6,13$ & $73,04 \pm 6,40$ & $75,33 \pm 5,58$ & 0,086 & 0,669 & 0,194 \\
\hline $15^{\prime}$ pasca ekstubasi & $75,79 \pm 6,80$ & $72,54 \pm 4,72$ & $75,21 \pm 7,66$ & 0,088 & 0,757 & 0,160 \\
\hline 20' pasca ekstubasi & $74,13 \pm 4,03$ & $73,63 \pm 4,99$ & $73,25 \pm 5,10$ & 0,715 & 0,524 & 0,784 \\
\hline $25^{\prime}$ pasca ekstubasi & $74,96 \pm 3,82$ & $72,17 \pm 4,17$ & $74,46 \pm 5,13$ & 0,032 & 0,076 & 0,076 \\
\hline 30' pasca ekstubasi & $75,75 \pm 4,08$ & $75,13 \pm 3,30$ & $74,75 \pm 4,20$ & 0,579 & 0,375 & 0,739 \\
\hline \multicolumn{7}{|l|}{ TD Sistolik } \\
\hline 5' pra induksi & $125,00 \pm 13,65$ & $122,58 \pm 12,76$ & $126,21 \pm 13,14$ & 0,528 & 0,752 & 0,344 \\
\hline 0' pasca ekstubasi & $114,08 \pm 25,10$ & $118,96 \pm 6,32$ & $117,50 \pm 6,50$ & 0,277 & 0,445 & 0,744 \\
\hline 5' pasca ekstubasi & $121,67 \pm 7,97$ & $119,42 \pm 7,99$ & $119,63 \pm 6,45$ & 0,303 & 0,349 & 0,924 \\
\hline $10^{\prime}$ pasca ekstubasi & $121,00 \pm 7,48$ & $120,71 \pm 6,83$ & $119,75 \pm 5,85$ & 0,881 & 0,523 & 0,625 \\
\hline $15^{\prime}$ pasca ekstubasi & $121,67 \pm 9,30$ & $119,04 \pm 6,07$ & $119,21 \pm 8,02$ & 0,254 & 0,285 & 0,942 \\
\hline 20 ' pasca ekstubasi & $120,67 \pm 6,78$ & $121,67 \pm 4,98$ & $119,00 \pm 7,25$ & 0,591 & 0,371 & 0,154 \\
\hline $25^{\prime}$ pasca ekstubasi & $120,96 \pm 5,36$ & $119,33 \pm 5,16$ & $118,79 \pm 7,80$ & 0,369 & 0,232 & 0,764 \\
\hline 30' pasca ekstubasi & $120,83 \pm 4,66$ & $120,08 \pm 5,40$ & $120,17 \pm 7,89$ & 0,674 & 0,708 & 0,963 \\
\hline \multicolumn{7}{|l|}{ T A R } \\
\hline 5' pra induksi & $92,17 \pm 9,72$ & $89,63 \pm 8,74$ & $93,42 \pm 9,59$ & 0,350 & 0,645 & 0,165 \\
\hline 0' pasca ekstubasi & $87,92 \pm 6,01$ & $87,79 \pm 5,35$ & $88,33 \pm 5,08$ & 0,937 & 0,794 & 0,734 \\
\hline 5' pasca ekstubasi & $89,33 \pm 5,72$ & $88,08 \pm 5,62$ & $89,42 \pm 4,43$ & 0,416 & 0,957 & 0,385 \\
\hline 10 'pasca ekstubasi & $90,88 \pm 5,77$ & $88,50 \pm 5,67$ & $89,79 \pm 4,62$ & 0,131 & 0,488 & 0,408 \\
\hline $15^{\prime}$ pasca ekstubasi & $90,75 \pm 6,56$ & $87,67 \pm 4,02$ & $89,67 \pm 6,62$ & 0,073 & 0,524 & 0,241 \\
\hline $20^{\prime}$ pasca ekstubasi & $89,38 \pm 4,15$ & $89,58 \pm 4,16$ & $88,13 \pm 4,80$ & 0,870 & 0,326 & 0,253 \\
\hline 25 ' pasca ekstubasi & $90,04 \pm 3,40$ & $87,58 \pm 3,46$ & $88,92 \pm 5,12$ & 0,040 & 0,342 & 0,261 \\
\hline 30' pasca ekstubasi & $90,33 \pm 3,29$ & $89,71 \pm 2,73$ & $89,54 \pm 4,35$ & 0,541 & 0,439 & 0,870 \\
\hline \multicolumn{7}{|l|}{ Laju jantung } \\
\hline 5' pra induksi & $85,25 \pm 11,88$ & $84,71 \pm 15,10$ & $82,63 \pm 7,70$ & 0,876 & 0,449 & 0,548 \\
\hline 0' pasca ekstubasi & $81,46 \pm 10,64$ & $79,71 \pm 9,20$ & $80,38 \pm 7,14$ & 0,508 & 0,682 & 0,801 \\
\hline 5' pasca ekstubasi & $80,46 \pm 9,60$ & $78,67 \pm 9,72$ & $79,29 \pm 6,80$ & 0,494 & 0,660 & 0,807 \\
\hline 10' pasca ekstubasi & $78,50 \pm 8,76$ & $79,00 \pm 7,55$ & $79,21 \pm 6,20$ & 0,820 & 0,747 & 0,924 \\
\hline 15 ' pasca ekstubasi & $98,54 \pm 1,10$ & $98,25 \pm 1,11$ & $98,63 \pm 0,92$ & 0,866 & 0,792 & 0,923 \\
\hline 20 ' pasca ekstubasi & $79,04 \pm 8,08$ & $75,83 \pm 8,47$ & $77,83 \pm 8,04$ & 0,180 & 0,611 & 0,401 \\
\hline $25^{\prime}$ pasca ekstubasi & $77,00 \pm 6,06$ & $75,71 \pm 7,23$ & $73,13 \pm 5,79$ & 0,486 & 0,313 & 0,753 \\
\hline 30' pasca ekstubasi & $78,17 \pm 4,22$ & $76,92 \pm 6,63$ & $74,67 \pm 5,22$ & 0,430 & 0,029 & 0,157 \\
\hline \multicolumn{7}{|l|}{ Saturasi $\mathrm{O}_{2}$} \\
\hline 5' pra induksi & $98,92 \pm 0,72$ & $99,04 \pm 0,70$ & $98,96 \pm 0,86$ & 0,570 & 0,850 & 0,705 \\
\hline 0' pasca ekstubasi & $99,50 \pm 0,72$ & $99,67 \pm 0,70$ & $99,46 \pm 0,83$ & 0,447 & 0,849 & 0,342 \\
\hline 5' pasca ekstubasi & $99,08 \pm 1,06$ & $98,67 \pm 1,04$ & $99,04 \pm 0,90$ & 0,157 & 0,849 & 0,342 \\
\hline $10^{\prime}$ pasca ekstubasi & $98,58 \pm 1,25$ & $98,54 \pm 1,21$ & $98,50 \pm 1,02$ & 0,902 & 0,805 & 0,902 \\
\hline $15^{\prime}$ pasca ekstubasi & $98,54 \pm 1,10$ & $98,25 \pm 1,11$ & $98,63 \pm 0,92$ & 0,339 & 0,784 & 0,220 \\
\hline 20' pasca ekstubasi & $98,25 \pm 1,15$ & $98,46 \pm 0,88$ & $98,21 \pm 0,97$ & 0,477 & 0,887 & 0,394 \\
\hline $25^{\prime}$ pasca ekstubasi & $98,50 \pm 1,06$ & $98,54 \pm 1,02$ & $98,58 \pm 1,14$ & 0,894 & 0,789 & 0,894 \\
\hline 30' pasca ekstubasi & $98,54 \pm 1,10$ & $98,42 \pm 1,10$ & $98,42 \pm 0,92$ & 0,680 & 0,680 & 1,000 \\
\hline
\end{tabular}

Keterangan : TAR : Tekanan arteri rerata.

Uji statistik menggunakan One-way Anova, dinyatakan dalam rerata \pm simpang baku.

p* : uji statistik tramadol dibandingkan meperidin.

$\mathrm{p}^{* *}$ : uji statistik tramadol dibandingkan kontrol.

$\mathrm{p}^{* * *}$ : uji statistik meperidin dibandingkan kontrol. 
Tabel 4. Kejadian, derajat dan durasi menggigil ketiga kelompok perlakuan.

\begin{tabular}{|c|c|c|c|c|}
\hline Variabel & $\begin{array}{c}\text { Kelompok T } \\
(\mathrm{n}=24) \\
\end{array}$ & $\begin{array}{c}\text { Kelompok M } \\
(\mathrm{n}=24)\end{array}$ & $\begin{array}{c}\text { Kelompok K } \\
(\mathrm{n}=24)\end{array}$ & $\mathbf{p}$ \\
\hline Kejadian menggigil & 4 & 4 & 13 & $\begin{array}{c}1,000 * \\
\mathbf{0 , 0 0 3} * * \\
\mathbf{0 , 0 0 3} * * * \\
\end{array}$ \\
\hline \multicolumn{5}{|l|}{ Derajat menggigil } \\
\hline 0 & 20 & 20 & 11 & \\
\hline 1 & 4 & 4 & 7 & $1,000^{*}$ \\
\hline 2 & - & - & 3 & $0,000 * *$ \\
\hline 3 & - & - & 2 & $0,000 * * *$ \\
\hline 4 & - & - & 1 & \\
\hline Durasi menggigil & $107,50 \pm 20,20$ & $105,25 \pm 20,09$ & $93,46 \pm 26,09$ & $\begin{array}{c}0,897 * \\
0,325 * * \\
0,407 * * *\end{array}$ \\
\hline
\end{tabular}

Keterangan : Uji statistik menggunakan One-way Anova, dengan derajat kemaknaan $\mathrm{p}<0,05$.

* : uji statistik tramadol dibandingkan meperidin.

** : uji statistik tramadol dibandingkan kontrol.

*** : uji statistik meperidin dibandingkan kontrol.

Tabel 5. Perbedaan pengukuran suhu tubuh ketiga kelompok perlakuan

\begin{tabular}{|c|c|c|c|c|}
\hline Suhu tubuh & $\begin{array}{c}\text { Kelompok T } \\
(\mathrm{n}=24)\end{array}$ & $\begin{array}{c}\text { Kelompok M } \\
(\mathrm{n}=24)\end{array}$ & $\begin{array}{c}\text { Kelompok K } \\
(\mathrm{n}=24)\end{array}$ & $\mathbf{p}$ \\
\hline Segera setelah intubasi & $37,371 \pm 0,1083$ & $37,379 \pm 0,0977$ & $37,362 \pm 0,1013$ & $\begin{array}{c}0,779 * \\
0,779 * * \\
0,575^{* * *}\end{array}$ \\
\hline Akhir operasi & $35,479 \pm 0,4000$ & $35,479 \pm 0,3755$ & $35,642 \pm 0,5508$ & $\begin{array}{c}1,000^{*} \\
0,214 * * \\
0,214 * * *\end{array}$ \\
\hline 15 menit pasca ekstubasi & $36,000 \pm 0,3890$ & $36,404 \pm 0,4428$ & $36,221 \pm 0,4501$ & $\begin{array}{c}\mathbf{0 , 0 0 2} * \\
0,078 * * \\
0,078 * * *\end{array}$ \\
\hline
\end{tabular}

Keterangan : Uji statistik menggunakan One-way Anova, dengan derajat kemaknaan $\mathrm{p}<0,05$.

* : : uji statistik tramadol dibandingkan meperidin.

** : uji statistik tramadol dibandingkan kontrol.

*** : uji statistik meperidin dibandingkan kontrol. 
Tabel 6. Efek samping pemberian obat pada ketiga kelompok perlakuan.

\begin{tabular}{lcccc}
\hline Efek Samping & $\begin{array}{c}\text { Kelompok T } \\
(\mathrm{n}=24)\end{array}$ & $\begin{array}{c}\text { Kelompok M } \\
(\mathrm{n}=24)\end{array}$ & $\begin{array}{c}\text { Kelompok K } \\
(\mathrm{n}=24)\end{array}$ & $\mathbf{p}$ \\
\hline & & & & \\
Mual & 2 & 6 & 0 & $\mathbf{0 , 0 0 6 *}$ \\
\hline Mual dan muntah & 0 & 2 & 0 & $0,485^{* *}$ \\
\hline
\end{tabular}

Keterangan : Uji statistik menggunakan One-way Anova, dengan derajat kemaknaan $\mathrm{p}<0,05$.

* $\quad$ : uji statistik tramadol dibandingkan meperidin.

** : uji statistik tramadol dibandingkan kontrol.

*** : uji statistik meperidin dibandingkan kontrol.

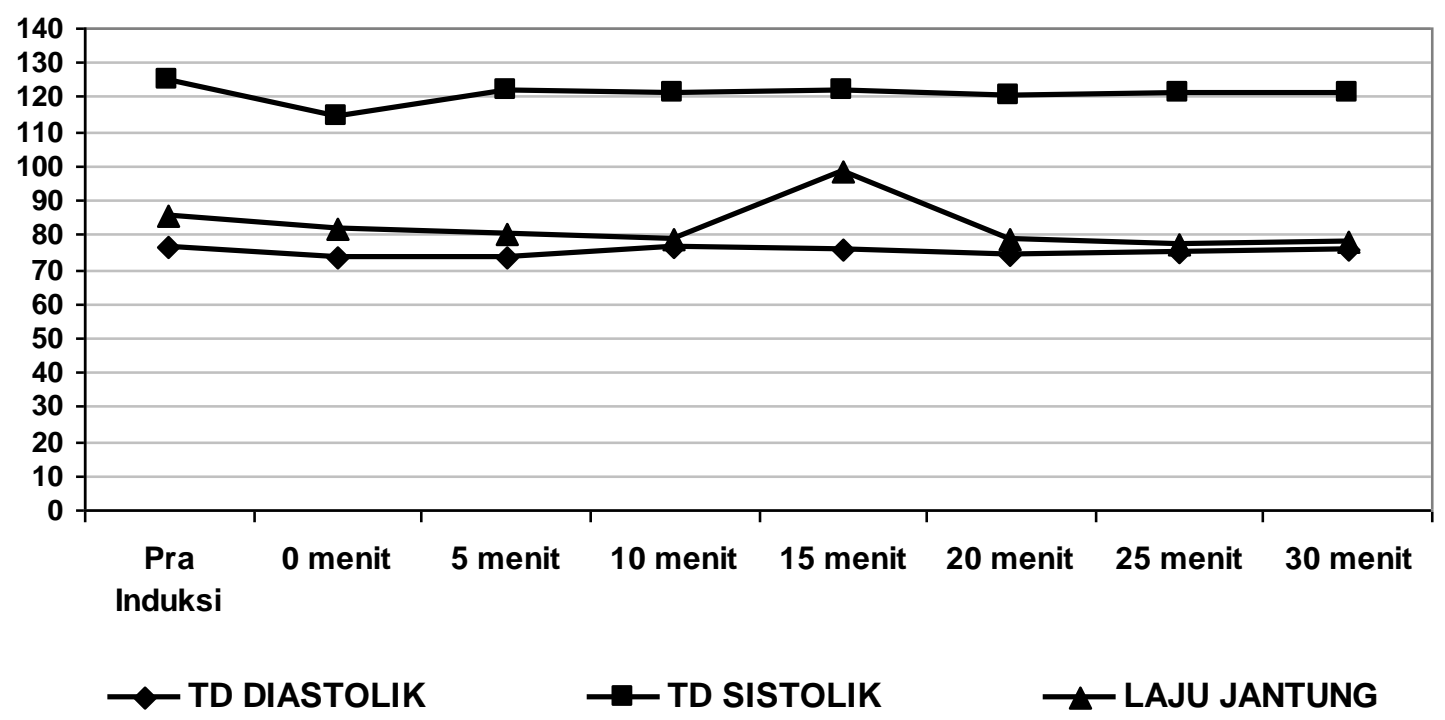

Grafik 1. Rerata kenaikan tekanan darah sistolik, tekanan darah diastolik dan laju jantung pada kelompok tramadol.

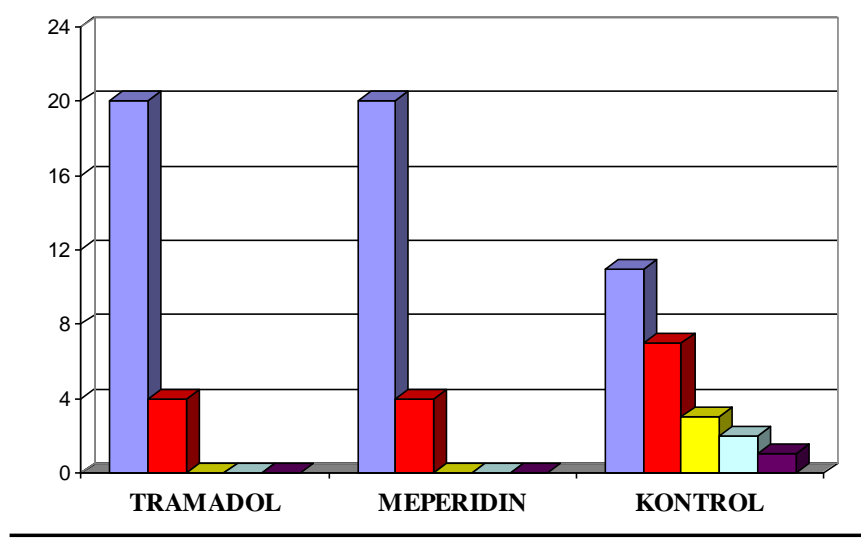

$\square$ Derajat $0 \quad \square$ Derajat $1 \quad \square$ Derajat $2 \quad \square$ Derajat $3 \quad \square$ Derajat 4

Grafik 2. Perbandingan kejadian dan derajat menggigil dari ketiga kelompok perlakukan. 


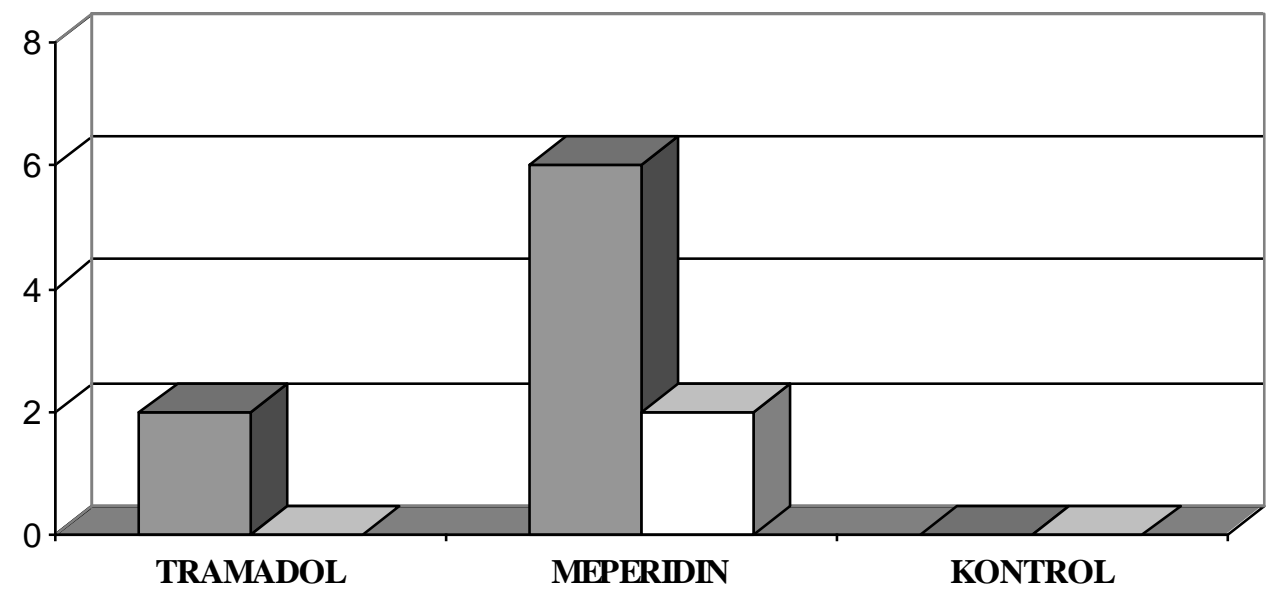

$\square$ Mual

$\square$ Mual \& muntah

Grafik 3. Efek samping obat pada ketiga kelompok perlakuan.

\section{DAFTAR PUSTAKA}

1. Morgan GE, Mikhail MS, Murray MJ, Larson CP. Clinical Anesthesiology $5^{\text {th }}$ ed. New York : Lange Medical Books/McGrawHill Medical Publishing Edition, 2013 : 1257-75.

2. Tsai YC, Chu KS. A comparison of tramadol, amitriptyline, and meperidine for postepidural anesthetic shivering in parturients. Anesth Analg 2001 ; 93:1288 1292.

3. Goold JE. Post operative spaticity and shivering. Anaesthesia, 1984 ; $39: 35-8$.

4. Schawarzkopt KR, Hoft H, Hartman M, Fritz HG. A comparison between meperidine, clonidine and urapidil in the treatment of postanesthetic shivering. Anesth Analg 2001 ; 95:257 - 60 .
5. Piper Sn, Maleck WH, Bolt J, Suttner SW, Schmidt CC, Reich DGP. A comparison of urapadil, clonidine, meperidine, and placebo in preventing postanesthetic shivering. Anesth Analg 2000 ; 90:954 - 7 .

6. Horn EP. Physostigminprevents post anesthetic shivering as does meperidine or clonidine. Anesthesiology, $1998 ; 88: 108$ 13.

7. Wang JJ, Ho ST, Lu SC, Liu YC. A comparison among nalbuphine, meperidine and placebo for treating postanesthetic shivering. Anesth Analg 1999 ; 88:686 - 9.

8. Sessler DI. Temperature regulation and monitoring. In : Miller RD. ed Miller's Anesthesia. $8^{\text {th }}$ ed. Philadelphia: Elsevier Saunders $2015 ; 1622-46$. 
9. Rosa G, Pinto G, Orsi P. Control of post anesthetic shivering with nefopam hydrochloride in midly hypothermi patients after neurosurgery. Acta Anaesthesiologica Scandinavia 1995 ; 39 (1):90-5.

10. Horn EP, Warner C, Sessler DI., et al. Late intraoperative clonidine administration prevents post anesthetic shivering after total intravenous and volatile anesthesia. Anesth Analg 1997 ; $84: 613-7$.

11. De Witte J, Sesler DI. Perioperative shivering : physiologuy and pharmacology. Anesthesiology $2002: 79: 467$ 84.

12. Chan AMH, Ng KFJ, Tong EWN, Jan GSK. Control of shivering under regional anesthesia in obstetric patiens with tramadol. Can J Anesth 1999 / $46 / 253-8$.

13. Duthie DJR. Remifentanil and tramadol, recent advances in opioid pharmacology. Br. J. Anaesth. 1998; 81:51 - 7 .

14. Bhatnagar S., Saxena A., Kannan TR., Punj J., Panigrahi M., Mishra S. Tramadol for post operative shivering : a double blind comparison with pethidine. Anaesthesia and Intensive Care $2001 ; 29: 149-54$.

15. Mathews S., Al Mulia A., Varghese PK, Radim K, Mumtaz S. Postanesthetic shivering - a new look at tramadol. Anaesthesia $2000,57: 387-403$.
16. De Witte J., Deloof T., De Veylder J., Housmans PR. Tramadol in the treatment of postanaesthetic shivering. Acta Anaesthesiologica Scandinavia $1997 ; 41$ : 506 - 10 .

17. Budd K, Langford R. Tramadol revisited. Br. J. Anaesth. 1999; $82: 493-5$.

18. Aitkenhead AR, Moppet IK, Thompson JP. Smith \& Aitkenhead Textbook of anaesthesia. $6^{\text {th }}$ eds. London: Churchill Livingstone, 2013: 843-86.

19. De Witte J, Rietman GW, Vandenbroucke G, Dellof T. Postoperative effects of tramadol administered at wound closure. Eur J Anaesthesiol. 1998 Mar;15(2): $190-5$.

20. Pausawasdi S, Jirasirithum S, Phanarai C. The use of tramadol hydrochloride in the treatment of post-anesthetic shivering. J Med Assoc Thai. 1990 Jan;73(1): 16 20.

21. Mohta M, Kumari N, Tyagi A, Sethi AK, Agarwal D, Sigh M. Tramadol for prevention of postanestetic shivering: a randomised doble blind comparison with pethidine. Anesthesia 2009, 64 (2): 141-6.

22. Sarim BY, Budiono U. Ketamin dan meperidin untuk pencegahan menggigil pasca anestesi umum. Jurnal Anestesiologi Indonesia 2011, $3: 95$ - 107.

23. Fatoni AZ, Isngadi, Jaya W. Perbandingan efek pemberian ondansetron dan petidin intravena untuk mencegah menggigil pasca 
anestesi umum. Jurnal menggigil pada sectio cesarea Anestesiologi Indonesia 2014, 6 : dengan anestesi spinal. Jurnal $89-99$. Anestesiologi Indonesia 2015, 7 :

24. Budiono U. Meperidin, ketamin $120-132$. dan klonidin efektif untuk terapi 